専門医症例報告

\author{
顎義歯とエピテーゼを装着した 1 症例 \\ 津田＼cjkstart賢治
}

\title{
A Case Report of Maxillofacial Prosthesis
}

Kenji Tsuda

抄 録

症例の概要：患者は 77 歳の男性。腫瘍により上顎骨の半側，眼窩底を含む右側煩骨および，右眼球を摘 出されている.

治療計画と経過：安定感のある上顎顎義歯および，審美的な回復のための眼窩部エピテーゼの作製を治療 計画として，上顎顎義歯を作製し，続いて顔面印象，ワックスアップ，シリコーンへの置換および着色・ 仕上げの工程を経て, 眼窩部エピテーゼを完成した。

考察：上顎顎義歯は，中空型とすることで安定性が確保された。眼窩部エピテーゼは審美的には患者の満 足が得られたが，着脱が容易でないなど問題は残った。

結論：症例毎に臨床条件の差が大きい顎顔面補綴症例においては，それぞれに適した処置が重要である。

和文キーワード

顎顔面補綴，顎義歯，エピテーゼ

\section{ABSTRACT}

Patient: A 77-year-old male patient who was undergone hemi-maxillectomy including removal of the zygomatic bone, orbit and eyeball on his right side due to cancer. His chief complaint was to gain the stable orbital prosthesis at the first examination. The fabrication of an upper complete denture, a lower removal partial denture and an orbital prosthesis were planned for functional and esthetic rehabilitation. At first, intraoral prostheses were fabricated, then, an orbital prosthesis was completed through the facial impression, sculpture, transfer the silicone material and coloration as following the conventional method.

Discussion: It was confirmed that the oral function was improved with the hollow obturator on the upper jaw, while some problems for the orbital prosthesis such as the difficulty in daily handling have remained.

Conclusion: In fabrication of maxillofacial prostheses, every clinical steps should be carefully done depending on rather complicated clinical conditions of individual patient.

\section{Key words}

maxillofacial prosthetics, denture for defected jaw, facial prosthesis 


\section{I . 緒 言}

腫瘍や外傷に因り，顎顔面領域の一部に欠損が生じた 症例において, 顎顔面補綴治療は外科的再建処置に順じ て, 臨床的に重要な対処法である. 上顎に欠損が生じた 場合, 無歯顎症例では総義歯型の䫈義歯が作製されるが, 咀嚼機能の回復のためには, 機能時における顎義歯の維 持・安定を図らなければならない。一般に全部床義歯は 義歯床と顎提粘膜との間に生じる陰圧による吸着力ゃ 解剖学的な顎提形態によって維持を得ているとされる が，上顎欠損症例では，これらの要件が満たされないこ とが多い. また，顎欠損部においては，当然のことなが ら咬合力を負担する支持組織が存在しない.これらのこ とが，顎義歯による機能回復を困難にしている.

また，顔面に欠損が生じた場合，エピテーゼが作製さ れる。エピテーゼは審美的改善に限れば, 外科的再建に 勝る場合も多いとされるが，その設計が欠損部形状や可 動状態に大きく左右されることや, 適合性, 色調, およ び形態の回復など多くのことを考慮して作製する必要 がある。

本症例においては，上顎骨の半側，眼窩底を含む右側 煩骨および右眼球を摘出しており，比較的大きな欠損へ の補経処置として, 上㖽顎義歯と眼窩部エピテーゼを作 製した。

\section{II. 症例の概要}

77 歳 男性 大正 14 年 6 月 29 日生 初診日 平成 14 年 9 月 9 日

患者は昭和 19 年に右眼窩部良性腫瘍を初発したが, 昭和 36 年右眼球を含む眼窩部切除, 続いて平成 12 年, 右上顎洞癌を発症し, 同部の切除術および左大腿部より グラフト手術, 頭蓋底部切除および頭蓋骨再建, 更には 平成 13 年右上顎癌, 鼻部癌切除と手術を繰り返し, 最 終的には, 上顎骨の半側を切除, 更に, 右眼窩底を含む 右側煩骨および右眼球の摘出を受けている（図 1)。し たがって, 右眼窩部から口腔内が直視できるという状況 であった。患者は初診時, 下顎に両側遊離端義歯を装着 し，上顎にはわずかに上顎欠損部への立ち上がりが付与 された全部床義歯を装着していた。この上顎全部床義歯 は, 平成 12 年の右上顎洞癌の手術直後に作製されたも ので, 当時は開口量が $1 \mathrm{c} \mathrm{m}$ 以下と開口障害が強かっ たため, 人工歯の排列を一部低位にするといった工夫も なされたものであり (図 2), そこから流動食を注入し ていた。しかし, 続く平成 13 年の右上顎癌および鼻部

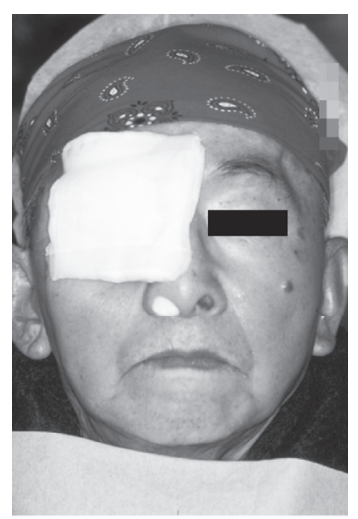

図 1 Frontal facial view at the first examination 患者初䛦時
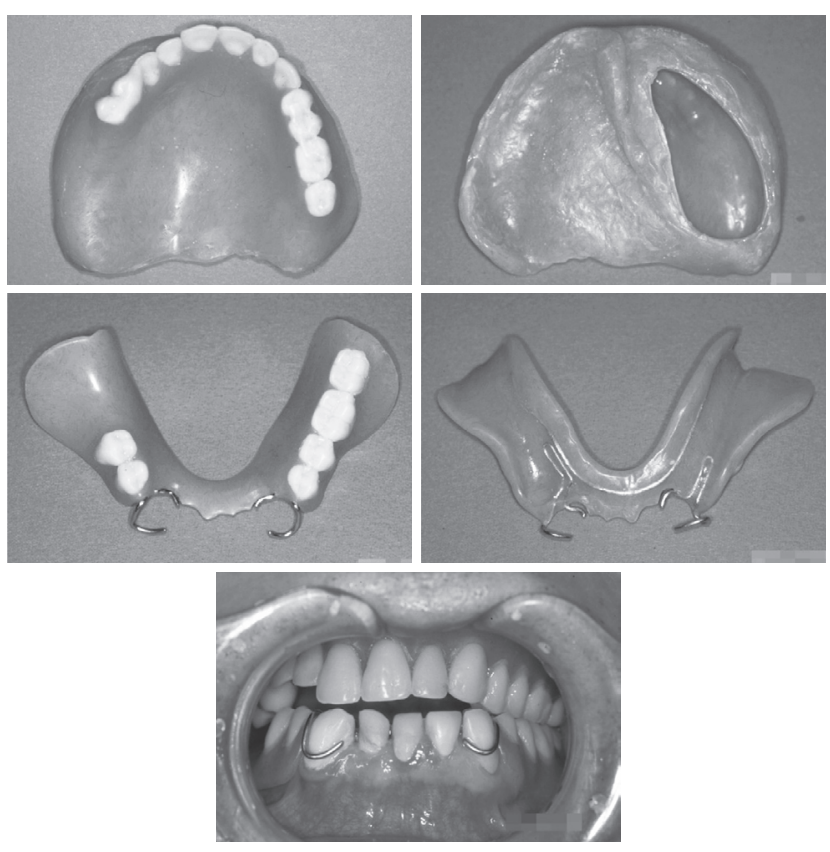

図 2 Previous prostheses 旧義歯

癌切除により, 義歯の不適合が起こり，開口時などに簡 単に脱離する状態となったため, 食事や会話など日常生 活において不都合を生じていた。

また，欠損部である右眼窩周辺を常にガーゼにて覆う 必要があり, 同部の審美的な回復を望んでいた。

右側上顎骨半側欠損，右眼窩部欠損の診断の下に，食 事や会話などの機能改善を目的とした安定感のある上 顎顎義歯，下顎部分床義歯および顔面欠損部における審 美的な回復のための眼窩部エピテーゼの作製を行うこ ととした。 

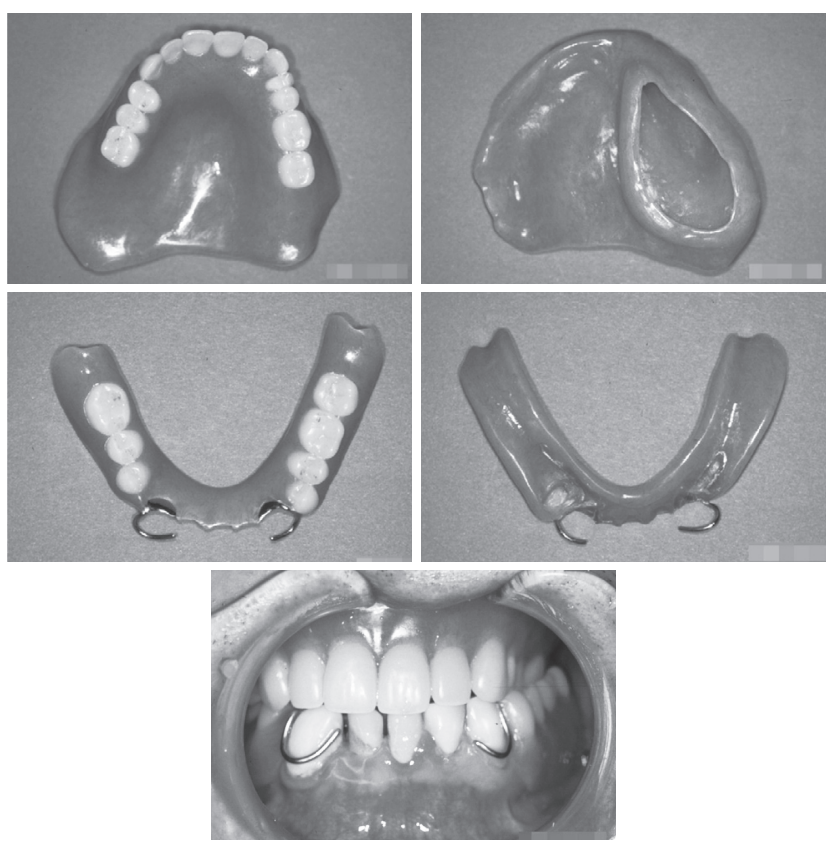

図 3 Final prostheses 新義歯

\section{III．治療内容と経過}

\section{1. 顎義歯}

治療計画に従い，旧義歯の調整および残存歯の充填な どの補綴前処置を行った後，上顎顎義歯および下顎部分 床義歯の作製を開始した。この時点では，切歯部の開口 量は $3 \mathrm{~cm}$ 程あったので，通法に従い概形印象採得，個 人トレーを用いた精密印象採得，咬合採得を行い，さら に，蛕義歯試適時には患側の沈み込久を考慮した咬座印 象を行った。

また，下顎の偏位や義歯の安定を考慮した結果，健側 人工臼歯は交叉咬合排列とした。

平成 14 年 12 月 25 日, 下顎部分床義歯および上顎䫈 義歯を装着した（図 3)。当初作製した上顎顎義歯は天 蓋開放型とした。患者の上顎骨欠損部は口腔内から顔面 欠損部へと大きく交通していたため，上顎嵿義歯は全部 床義歯型であったが，本来維持力として期待すべき陰圧 による吸着はないに等しいものであった。そのため，才 ブチュレータ部と欠損部との適合に苦慮し, 削除調整と リラインを繰り返す必要があった。平成 15 年 4 月 4 日, 上顎顎義歯が落ち着いたところで，顎義歯の天蓋開放部 分に浸出液がたまるとの訴えもあり, 顎義歯は中空型に 改造した。
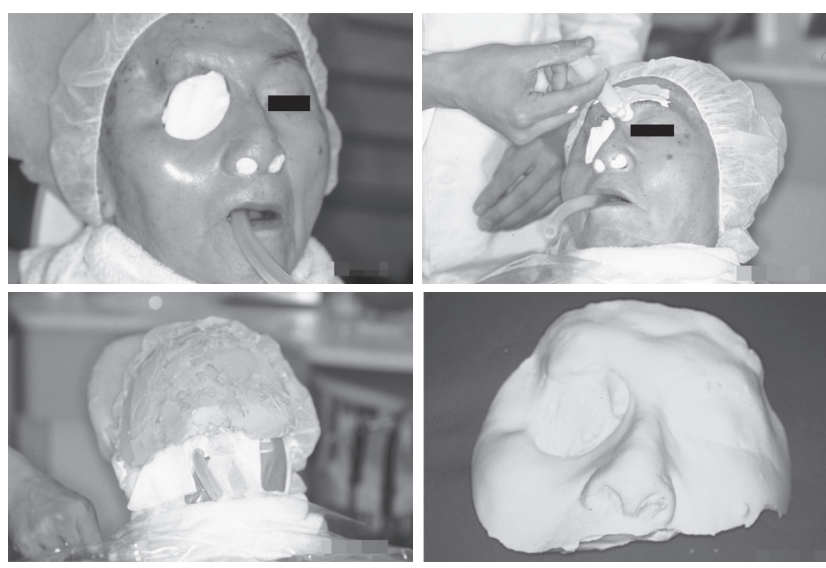

図 4 Facial impression 顔面印象
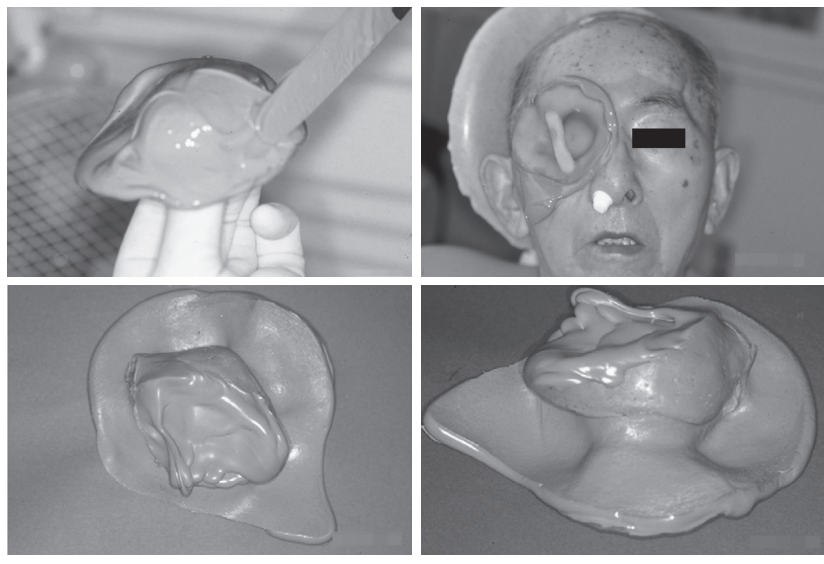

図 5 Final facial impression 精密印象

\section{2. エピテーゼ}

顔面の概形模型を作製する目的で顔面印象を行い ${ }^{1,2)}$ (図 4), 模型上でエピテーゼ印象用のオストロントレー を作製し，精密印象採得を行った（図 5)。作業用模型 上でワックスアップを行い（図 6)，数回の試適・修正 の後, ワックスアップを完成した。続いて，エピテーゼ の材料であるシリコーン樹脂のベースとキャタリスト を指定された 10：1の重量比で混合し，内部色素顔料 を混ぜてベース色を決定した，埋没・流蝻された鋳型に 気泡を巻き込まないように混合したシリコーンを入れ， $80^{\circ} \mathrm{C}$ のお湯に 5 分間浸漬し,加硫による成形を行った(図 7)。義眼は既製の物を使用した。

加硫を終えたエピテーゼにシリコーンアドヒーシブ とエチレンに溶いた顔料を用いて外部着色を行う工程 においては，チェアサイドで患者の皮膚色に適合させる ように行ったが，なかなか満足が得られず，4回の来院 

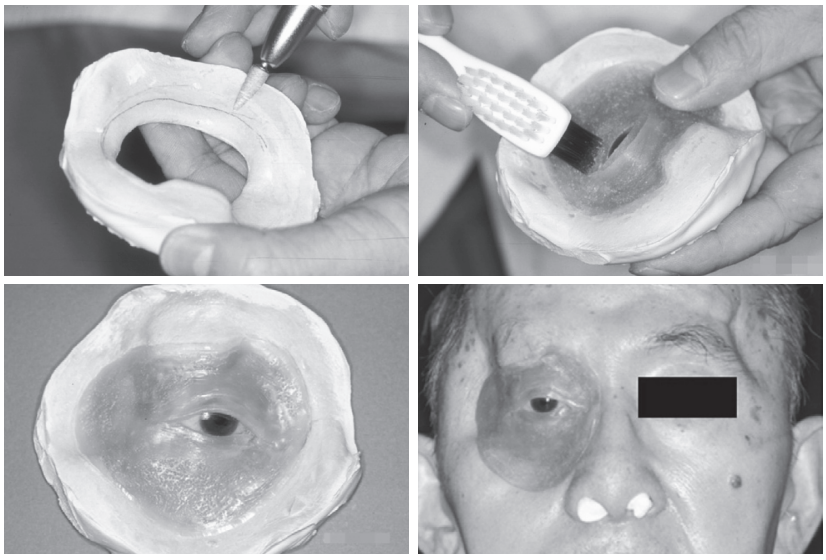

図 6 Wax sculpture

ワックスアップ

が必要であった。続いて仕上げの工程を経て, 眼窩部工 ピテーゼを完成した（図 8).

\section{IV. 考 察}

上顎頡義歯は，装着時は天蓋開放型としたが，浸出液 がたまるとの訴えがあり, 中空型の顎義歯に改造するこ とで結果的に安定感が増したが, 大型化により着脱は若 干難しくなった。 また, 浸出液が溜まらないので, 快適 で臭いがない等の利点が見られたが，浸出液は鼻孔から 出るか, 口腔内に流入するため, 鼻腔からの鼻汁と混ざっ た浸出液がたくさん出ることや，口腔内が変な味がする 等欠点の訴えもあった。

上顎顎義歯は，その後，2度のリベースを行った。

眼窩エピテーゼは, 審美的に患者の満足は得られたが, 軟性素材で作られており, 同じく軟組織である顔面表皮 に装着する際，想定した位置が確認し辛く，僅かに位置 や角度がずれただけで違和感が大きかった．特に患者一 人で上手に装着するのは困難であるなど問題は残った。

\section{V. 結 論}

本症例報告は比較的大きな上顎欠損と眼窩部欠損に 対して, 中空型の上顎顎義歯と眼窩エピテーゼを作製し たものである，症例毎に臨床様相の違いの大きい顎顔面 補経症例においては，患者の欠損状態を把握し，それぞ れの症例に適した処置を的確に選択することが重要で ある。
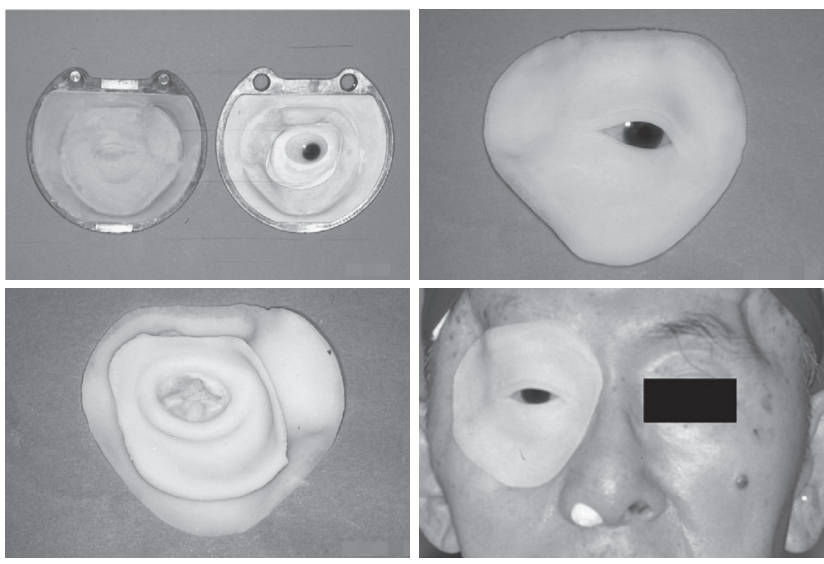

図 7 Flasking and vulcanization シリコーンの加硫化
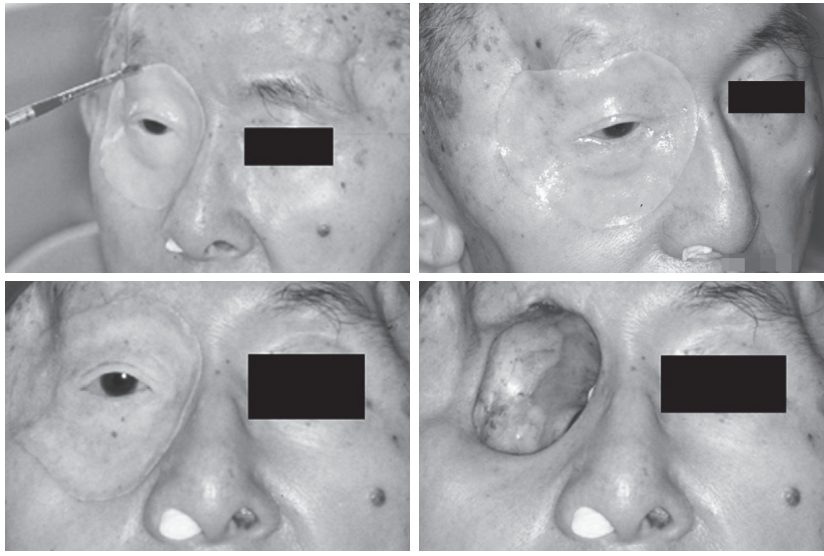

図 8 Extrinsic coloring and completed facial prosthesis

エピテーゼの着色・完成

\section{文献}

1) 田中貴信, 岸本康男. わ扎わ扎の顎顔面補綴治療. Dental Diamond 1983; 8(10): 24-30.

2) Tanaka Y, Gold HO, Pruzansky S. New facial impression technique in maxillofacial. Maxillofacial Prosthetics 1979; 2: 11-14.

著者連絡先：津田 賢治

干 464-8651 名古屋市千種区末盛通 2-11

TEL : 052-759-2152

FAX : 052-759-2152

E-mail : nakahana-shika@infoseek.jp 